\title{
EFEKTIVITAS PEMBERIAN MAKANAN TAMBAHAN PADA BALITA KURUS DAN SANGAT KURUS DI WILAYAH KERJA PUSKESMAS KAPASA KOTA MAKASSAR
}

\author{
M. SADLI UMASANGAJI ${ }^{1}$, ASWITA AMIR ${ }^{2}$ DAN SITTI SAHARIAH ROWA ${ }^{2}$ \\ ${ }^{1}$ Alumni Jurusan Gizi, Politeknik Kesehatan Kemenkes Makassar \\ 2 Jurusan Gizi, Politeknik Kesehatan Kemenkes Makassar \\ Korespondensi: msadliumasangaji@poltekkes-mks.ac.id \\ DOI : https://doi.org/10.35451/jkg.v4i1.791
}

\begin{abstract}
This study aims to determine the effectiveness of providing additional food to wasted and severely wasted in the working area of the Kapasa Health Center Makassar City. This research is a survey research with a cross sectional research design. The population in this study were all wasted and severely wasted toddlers who received Supplementary Food in the working area of the Kapasa Health Center. The sample used in this study is part of the population. The sampling technique in this research is purposive sampling. The number of samples in this study were 18 toddlers. The results of this study indicate that for the power of supplementary food consumption, most of the respondents are good as many as 12 toddlers (66.7\%), for changes in body weight most of the respondents are up by 14 toddlers (77.8\%), for changes in height or body length most of the respondents are No Increase as many as 10 toddlers (55.6\%). The results of the test using the Chi Square Test for Acceptance of Supplemental Food Consumption with Changes in Body Weight with a $p$ value of 0.045, meaning $p<0.05$, then there is additional feeding on changes in body weight. The test results using the Chi Square Test for Acceptance of Supplementary Food Consumption with Changes in Height with a $p$ value of 0.502 meaning $p>$ 0.05 then there is no additional feeding on changes in height or body length. It was concluded that offering additional food was effective against changes in body weight. However, offering additional food is not effective for changes in height or body length.
\end{abstract}

Keywords: Supplementary Feeding, Receptivity, Weight, Height, Body Length, Wasted Toddlers, Severely Wasted Toddlers

\section{PENDAHULUAN}

Wasting atau yang biasanya disebut balita kurus merupakan indikasi kekurangan gizi berdasarkan indeks antropometri dari Berat Badan Menurut Panjang Badan atau Tinggi Badan yang disebabkan karena ada kejadian dalam waktu singkat dan bersifat akut seperti kelaparan dan wabah penyakit yang mengakibatkan anak menjadi kurus.
Balita kurus yang berlangsung lama dapat menyebabkan peningkatan keparahan fisik, menurunkan fungsi sistem kekebalan tubuh, menyebabkan tingkat kerentanan anak mudah terhadap penyakit menular serta meningkatkan risiko kematian (Putri \& Mahmudiono, 2020).

Laporan Global Nutrition Report tahun 2015, World Health Organization (WHO) secara global memperkirakan 
prevalensi balita stunting sebesar 161 juta dan 51 juta prevalensi balita wasting (Afriza, 2016). Tahun 2018 data Global Nutrition Report menunjukkan data wasting secara global sebanyak $7.5 \%$ atau 50.5 juta pada balita usia 059 bulan (WHO, 2018). Data di Indonesia berdasarkan Hasil Pemantauan Status Gizi Tahun 2016 menunjukkan Balita Sangat Kurus sebanyak 3.1\% dan Balita Kurus sebanyak $8.0 \%$ dan atau Balita Sangat Kurus + Kurus sebanyak $11.1 \%$ (Kementerian Kesehatan, 2017). Tahun 2017 menunjukkan Balita Sangat Kurus sebanyak $2.8 \%$ dan Balita Kurus sebanyak $6.7 \%$ atau Balita Sangat Kurus + Kurus sebanyak 9.5\% (Kementerian Kesehatan, 2018). Hasil Riskesdas Tahun 2018 menunjukkan Balita Sangat Kurus sebanyak 3.5\% dan Balita Kurus sebanyak $6.7 \%$ atau Balita Sangat Kurus + Kurus sebanyak 10.2\% (Kementerian Kesehatan, 2019).

Data di Sulawesi Selatan berdasarkan Hasil Pemantauan Status Gizi Tahun 2016 menunjukkan Balita Sangat Kurus sebanyak 2.0\% dan Balita Kurus sebanyak $7.3 \%$ atau Balita Sangat Kurus + Kurus sebanyak 9.3\% ((Kementerian Kesehatan, 2017). Tahun 2017 menunjukkan Balita Sangat Kurus sebanyak 1.7\% dan Balita Kurus sebanyak $7.0 \%$ atau Balita Sangat Kurus + Kurus sebanyak $8.7 \%$ (Kementerian Kesehatan, 2018).

Pemberian Makanan Tambahan Pemulihan menjadi program yang dicanangkan pemerintah kepada usia balita dengan tujuan sebagai makanan pendukung atau tambahan selain makanan utama yang diberikan seharihari dalam memenuhi kebutuhan gizi balita. Sesuai dengan petunjuk teknis pemberian makanan tambahan maka sasaran yang diutamakan dalam pemberian makanan tambahan adalah balita usia 6-59 bulan dengan kategori kurus berdasarkan hasil pengukuran berat badan menurut panjang badan atau tinggi badan (BB/PB atau BB/TB) dengan nilai z-score kurang dari minus dua standar deviasi ( $<-2$ SD) dengan lama waktu pemberian adalah 90 hari makan sesuai aturan konsumsi (Putri \& Mahmudiono, 2020). Berdasarkan latar belakang inilah yang mendasari peneliti untuk melakukan penelitian tentang "Efektivitas Pemberian Makanan Tambahan Pada Balita Kurus dan Sangat Kurus di Wilayah Kerja Puskesmas Kapasa Kota Makassar".

\section{METODE PENELITIAN}

Penelitian ini merupakan penelitian observasional dengan jenis penelitian adalah penelitian survei dan desain penelitian ini adalah potong lintang (cross sectional). Penelitian ini dilakukan di Wilayah Kerja Puskesmas Kapasa Kecamatan Tamalanrea, Kota Makassar, Sulawesi Selatan. Penelitian ini dilakukan pada bulan Juli 2020 Januari 2021 dimana pengumpulan data wawancara daya terima dilakukan dari bulan Oktober sampai Desember 2020 selama 3 kali dan pengumpulan data berat badan, tinggi badan atau panjang badan setelah pemberian makanan tambahan di bulan Januari 2021. Populasi dalam penelitian ini adalah seluruh balita kurus dan sangat kurus yang mendapat Makanan Tambahan berada di wilayah kerja Puskesmas Kapasa. Sampel yang digunakan dalam penelitian ini adalah bagian dari populasi yang berjumlah 18 responden. Dimana dengan teknik pengambilan sampel yang digunakan adalah non probability sampling dengan jenis teknik purposive sampling. Kriteria Inklusi adalah bersedia mengikuti penelitian, mendapat makanan tambahan selama 30-90 hari, balita di wilayah kerja Puskesmas Kapasa. Kriteria Eksklusi adalah sedang dalam keadaan sakit 
berat saat penelitian, balita dengan penyakit kelainan tertentu. balita berpindah tempat tinggal.

Data karakteristik responden diperoleh dengan cara wawancara menggunakan kuesioner. Data daya terima makanan tambahan diperoleh dengan cara wawancara menggunakan kuesioner. Data berat badan setelah pemberian makanan tambahan diperoleh dengan melakukan penimbangan menggunakan timbangan digital. Data tinggi badan balita setelah pemberian makanan tambahan diperoleh dengan pengukuran menggunakan microtoise sedangkan panjang badan balita dengan pengukuran menggunakan lengthboard. Data sekunder diperoleh dari Puskesmas untuk data pencatatan balita kurus dan sangat kurus yang mendapat makanan tambahan serta data berat badan, tinggi badan, dan panjang badan awal sebelum pemberian makanan tambahan. Analisis data yang digunakan dalam penelitian ini adalah aplikasi software komputer statistika SPSS untuk melihat hubungan bermakna dengan menggunakan Uji Chi Square.

\section{HASIL}

Berdasarkan jenis kelamin, sebagian besar sampel adalah balita dengan jenis kelamin laki-laki. Untuk klasifikasi umur, sebagian besar sampel adalah balita dengan klasifikasi umur 24-59 bulan. Untuk pendidikan Ayah, sebagian besar responden dengan pendidikan ayah adalah Sekolah Dasar dan Sekolah Menengah Pertama. Untuk pendidikan Ibu, sebagian besar responden dengan pendidikan ibu adalah Sekolah Menengah Pertama. Untuk pekerjaan Ayah, sebagian besar responden dengan pekerjaan ayah adalah Buruh Harian. Untuk pekerjaan Ibu, sebagian besar responden dengan pekerjaan ibu adalah Mengurus Rumah Tangga. Untuk status gizi awal, sebagian besar sampel balita dengan status gizi awal adalah Kurus.

Berdasarkan Daya Terima, sebagian besar sampel balita dengan daya terima konsumsi makanan tambahan adalah Baik. Untuk Perubahan Berat Badan, sebagian besar sampel balita dengan Perubahan Berat Badan adalah Naik. Sebagian besar sampel balita dengan Daya Terima Konsumsi Makanan Tambahan dengan Perubahan Berat Badan adalah Baik dan Naik. Hasil pengujian statistik menggunakan Uji Chi Square menunjukkan bahwa nilai $p$ value 0.045 artinya $p<0.05$. Untuk Perubahan Tinggi Badan atau Panjang Badan, sebagian besar sampel balita dengan Perubahan Tinggi Badan atau Panjang Badan adalah Tidak Naik. Sebagian besar sampel balita dengan Daya Terima Konsumsi Makanan Tambahan dengan Perubahan Tinggi Badan atau Panjang Badan adalah Baik dan Tidak Naik. Hasil pengujian statistik menggunakan Uji Chi Square menunjukkan bahwa nilai $p$ value 0.502 artinya $\mathrm{p}>0.05$. 
Tabel 1.

Karakteristik Sampel dan Responden

\begin{tabular}{|c|c|c|c|}
\hline Karakteristik & Kategori & $\mathrm{n}$ & $\%$ \\
\hline \multirow{2}{*}{ Jenis Kelamin } & Laki-laki & 10 & 55.6 \\
\hline & Perempuan & 8 & 44.4 \\
\hline \multirow{2}{*}{$\begin{array}{l}\text { Klasifikasi } \\
\text { (Bulan) }\end{array}$} & $0-23$ & 6 & 33.3 \\
\hline & $24-59$ & 12 & 66.7 \\
\hline \multirow[t]{4}{*}{ Pendidikan Ayah } & Sekolah Dasar & 6 & 33.3 \\
\hline & Sekolah Menengah Pertama & 6 & 33.3 \\
\hline & Sekolah Menengah Atas & 5 & 27.8 \\
\hline & Pendidikan Tinggi & 1 & 5.6 \\
\hline \multirow[t]{4}{*}{ Pendidikan Ibu } & Sekolah Dasar & 5 & 27.8 \\
\hline & Sekolah Menengah Pertama & 7 & 38.9 \\
\hline & Sekolah Menengah Atas & 4 & 22.2 \\
\hline & Pendidikan Tinggi & 2 & 11.1 \\
\hline \multirow[t]{4}{*}{ Pekerjaan Ayah } & Belum Ada Pekerjaan & 1 & 5.6 \\
\hline & Buruh Harian & 8 & 44.4 \\
\hline & Karyawan & 6 & 33.3 \\
\hline & Sopir & 3 & 16.7 \\
\hline \multirow[t]{3}{*}{ Pekerjaan Ibu } & Karyawan & 1 & 5.6 \\
\hline & Mengurus Rumah Tangga & 14 & 77.7 \\
\hline & Wirausaha & 3 & 16.7 \\
\hline \multirow[t]{3}{*}{ Status Gizi Awal } & Kurus & 14 & 77.8 \\
\hline & Sangat Kurus & 4 & 22.2 \\
\hline & Total & 18 & 100.0 \\
\hline
\end{tabular}

(Sumber: Data Primer, 2021)

Tabel 2.

Daya Terima, Perubahan Berat Badan, dan Perubahan Tinggi Badan

\begin{tabular}{clcc}
\hline \multicolumn{1}{c}{ Variabel } & \multicolumn{1}{c}{ Kategori Variabel } & $\mathrm{n}$ & $\%$ \\
\hline Daya Terima & Baik & 12 & 66.7 \\
& Kurang & 6 & 33.3 \\
Perubahan Berat Badan & Naik & 14 & 77.8 \\
& Tidak Naik & 4 & 22.2 \\
\multirow{2}{*}{ Perubahan Tinggi Badan } & Naik & 8 & 44.4 \\
& Tidak Naik & 10 & 55.6 \\
\hline & Total & 18 & 100.0
\end{tabular}

(Sumber: Data Primer, 2021) 
Tabel 3

Daya Terima Konsumsi Makanan Tambahan dengan Perubahan Berat Badan

\begin{tabular}{|c|c|c|c|c|c|c|c|c|}
\hline \multirow{3}{*}{ No } & \multirow{3}{*}{$\begin{array}{c}\text { Daya Terima } \\
\text { Makanan } \\
\text { Tambahan }\end{array}$} & \multicolumn{4}{|c|}{ Perubahan Berat Badan } & \multirow{2}{*}{\multicolumn{2}{|c|}{ Total }} & \multirow{3}{*}{$\begin{array}{c}\mathrm{p} \\
\text { Value }\end{array}$} \\
\hline & & \multicolumn{2}{|c|}{ Naik } & \multicolumn{2}{|c|}{ Tidak Naik } & & & \\
\hline & & $\mathrm{n}$ & $\%$ & $\mathrm{~N}$ & $\%$ & $\mathrm{n}$ & $\%$ & \\
\hline 1 & Baik & 11 & 61.1 & 1 & 5.6 & 12 & 66.7 & \multirow{3}{*}{0.045} \\
\hline 2 & Kurang & 3 & 16.7 & 3 & 16.7 & 6 & 33.3 & \\
\hline & Total & 14 & 77.8 & 4 & 22.2 & 18 & 100 & \\
\hline
\end{tabular}

(Sumber: Data Primer, 2021)

Tabel 4

Daya Terima Konsumsi Makanan Tambahan dengan Perubahan Tinggi Badan atau Panjang Badan

\begin{tabular}{|c|c|c|c|c|c|c|c|c|}
\hline \multirow{3}{*}{ No } & \multirow{3}{*}{$\begin{array}{c}\text { Daya Terima } \\
\text { Makanan } \\
\text { Tambahan }\end{array}$} & \multicolumn{4}{|c|}{$\begin{array}{c}\text { Perubahan Tinggi Badan } \\
\text { atau Panjang Badan }\end{array}$} & \multirow{2}{*}{\multicolumn{2}{|c|}{ Total }} & \multirow{3}{*}{$\begin{array}{c}\mathrm{P} \\
\text { Value }\end{array}$} \\
\hline & & \multicolumn{2}{|c|}{ Naik } & \multicolumn{2}{|c|}{ Tidak Naik } & & & \\
\hline & & $\mathrm{n}$ & $\%$ & $n$ & $\%$ & $\mathrm{n}$ & $\%$ & \\
\hline 1 & Baik & 6 & 33.3 & 6 & 33.3 & 12 & 66.7 & \multirow{3}{*}{0.502} \\
\hline 2 & Kurang & 2 & 11.1 & 4 & 22.2 & 6 & 33.3 & \\
\hline & Total & 8 & 44.4 & 10 & 55.6 & 18 & 100 & \\
\hline
\end{tabular}

(Sumber: Data Primer, 2021)

\section{PEMBAHASAN}

Perhitungan daya terima dalam penelitian ini adalah dengan menghitung kalori atau energi dari hasil wawancara daya terima selama 3 kali kemudian dihitung rata-rata energi atau kalori tersebut. Setelah itu membandingkan dengan hasil perhitungan energi atau kalori dari salah satu perencanaan menu yang dibuat oleh puskesmas untuk makanan sehari sekali makan dimana diperoleh hasil sebesar 776.8 kalori.
Makanan Tambahan yang diberikan oleh Puskesmas Kapasa Kota Makassar pada bulan Oktober - Desember 2020 berupa makanan lengkap harian untuk sekali makan. Hasil penelitian terlihat bahwa dari 18 responden menunjukkan Daya Terima Konsumsi Makanan Tambahan sebagian besar adalah Baik sebanyak 12 balita $(66.7 \%)$, dan Kurang sebanyak 6 balita (33.3\%).

Pandangan Kementerian Kesehatan RI dalam (Herianto, 2017) bahwa ketentuan pemberian makanan tambahan untuk anak di 
bawah lima tahun atau usia pra sekolah dengan energi sekitar $200-$ 300 kalori dan protein sekitar 5-8 gram. Makanan Tambahan ini bisa dalam bentuk makanan selingan (snack) atau makanan lengkap dengan porsi kecil, yang diolah dari bahan makanan lokal. Dengan ragam bahan yang memenuhi protein nabati atau hewani, serta memenuhi unsur gizi seimbang, memakai resep daerah atau dimodifikasi, serta penyiapan dan pengolahan yang aman serta memenuhi ketentuan dari kebersihan dan juga kesehatan.

Perubahan berat badan dan tinggi badan atau panjang badan dalam penelitian ini dilihat dari pengukuran data awal pada bulan Oktober 2020 dengan data yang diperoleh dari Puskesmas dan penimbangan akhir dilakukan pada tanggal 16-17 Januari 2021. Dengan selang waktu kurang lebih 3 bulan. Tetapi sebagaimana penjelasan diatas bahwa pemberian makanan tambahan telah berjalan selama 62 hari atau kurang lebih 2 bulan.

Hasil penelitian ini terlihat bahwa dari 18 responden menunjukkan responden dengan Perubahan Berat Badan sebagian besar adalah Naik sebanyak 14 balita $(77.8 \%)$, dan Tidak Naik sebanyak 4 balita (22.2\%). Penelitian ini juga menunjukkan bahwa Berat Badan Sebelum Mendapat Makanan Tambahan dengan nilai minimum sebesar 6.6 $\mathrm{kg}$, nilai maksimum sebesar $11.6 \mathrm{~kg}$ dan nilai rerata sebesar $8.9 \mathrm{~kg}$. Sedangkan Berat Badan Setelah
Mendapat Makanan Tambahan dengan nilai minimum sebesar 6.6 $\mathrm{kg}$, nilai maksimum sebesar $12.1 \mathrm{~kg}$ dan nilai rerata sebesar $9.5 \mathrm{~kg}$. Dengan nilai rerata selisih berat badan adalah $0.5 \mathrm{~kg}$.

Penelitian ini juga menunjukkan responden dengan Daya Terima Konsumsi Makanan Tambahan dengan Perubahan Berat Badan sebagian besar adalah Baik dan Naik sebanyak 11 balita (77.3\%), Kurang dan Naik serta Kurang dan Tidak Naik masing-masing sebanyak 3 balita (16.7\%), Baik dan Tidak Naik sebanyak 1 balita (5.6\%). Hasil pengujian statistik menggunakan Uji Chi Square menunjukkan bahwa nilai $\mathrm{p}$ value 0.045 artinya $p<0.05$ maka ada hubungan yang bermakna artinya ada efektivitas pemberian makanan tambahan pada perubahan berat badan.

Penelitian ini sejalan dengan penelitian yang dilakukan oleh (Sugianti, 2017) di Kabupaten Tuban dalam melihat evaluasi pemberian makanan tambahan pemulihan pada balita gizi kurang dengan jumlah sampel adalah 26 balita. Penelitian tersebut dengan hasil analisis menunjukkan $\mathrm{p}$ value $<0.05$ yaitu 0.000 artinya ada perbedaan yang bermakna dari berat badan sebelum dan sesudah Pemberian Makanan Tambahan selama 90 Hari.

Pemberian Makanan Tambahan Pemulihan adalah tambahan sebagai makanan pendukung terhadap balita sasaran, artinya bukan sebagai alternatif dari makanan utama yang dikonsumsi 
sehari-hari dari balita sasaran. Adanya kenaikan berat badan bukan saja disebabkan Pemberian Makanan Tambahan Pemulihan. Akan tetapi beberapa faktor lain juga diasumsikan dapat mempengaruhi kenaikan berat badan dari balita yang diberikan Makanan Tambahan. Faktor itu diantaranya semisal asupan makanan utama serta juga makanan selingan dari balita sasaran (Sugianti, 2017).

Hasil penelitian ini terlihat bahwa dari 18 responden menunjukkan responden dengan Perubahan Tinggi Badan atau Panjang Badan sebagian besar adalah Tidak Naik sebanyak 10 balita $(55.6 \%)$, dan Naik sebanyak 8 balita (44.4\%). Penelitian ini juga menunjukkan bahwa Tinggi Badan atau Panjang Badan Sebelum Mendapat Makanan Tambahan dengan nilai minimum sebesar 70.0 $\mathrm{cm}$, nilai maksimum sebesar 96.0 $\mathrm{cm}$ dan nilai rerata sebesar 84.1 $\mathrm{cm}$. Sedangkan Tinggi Badan atau Panjang Badan Setelah Mendapat Makanan Tambahan dengan nilai minimum sebesar $70.5 \mathrm{~cm}$, nilai maksimum sebesar $96.0 \mathrm{~cm}$ dan nilai rerata sebesar $84.3 \mathrm{~cm}$. Dengan nilai rerata selisih tinggi badan atau panjang badan adalah $0.2 \mathrm{~cm}$.

Penelitian ini juga menunjukkan Daya Terima Konsumsi Makanan Tambahan dengan Perubahan Tinggi Badan atau Panjang Badan sebagian besar adalah Baik dan Naik serta Baik dan Tidak Naik masing-masing sebanyak 6 balita (33.3\%), Kurang dan Tidak Naik sebanyak 4 balita (22.2\%) serta Kurang dan Naik sebanyak 2 balita $(11.1 \%)$. Hasil pengujian statistik menggunakan $\mathrm{Uji}$ Chi Square menunjukkan bahwa nilai $\mathrm{p}$ value 0.502 artinya $p>0.05$ maka tidak ada hubungan yang bermakna artinya tidak ada efektivitas pemberian makanan tambahan pada perubahan tinggi badan atau panjang badan.

Penelitian ini sejalan dengan hasil penelitian yang dilakukan (Juhartini, 2015) di Wilayah Kerja Puskesmas Kalumpang Kota Ternate untuk Pemberian MT berbentuk Biskuit dengan analisis statistik yang menggunakan uji pearson menunjukkan bahwa kelompok yang mendapat PMT biskuit memiliki asupan energi yang tidak mempengaruhi perubahan tinggi badan $(p=0.368)$.

\section{KESIMPULAN DAN SARAN}

Kesimpulan yang dapat diambil dari penelitian ini adalah Daya Terima Konsumsi Makanan Tambahan sebagian besar adalah Baik sebanyak 12 balita $(66.7 \%)$, Perubahan Berat Badan sebagian besar adalah Naik sebanyak 14 balita $(77.8 \%)$ dimana rerata selisih berat badan adalah $0.5 \mathrm{~kg}$, Perubahan Tinggi Badan atau Panjang Badan sebagian besar adalah Tidak Naik sebanyak 10 balita (55.6\%), Pemberian Makanan Tambahan Efektif terhadap Perubahan Berat Badan (nilai $p$ value 0.045) dan Pemberian Makanan Tambahan Tidak Efektif terhadap Perubahan Tinggi Badan 
atau Panjang Badan (nilai $\mathrm{p}$ value 0.502).

Saran yang dapat diberikan dari penelitian ini adalah bagi ibu responden atau keluarga responden perlu termotivasi dalam memberikan Makanan Tambahan kepada anaknya (balita) sehingga Makanan Tambahan yang diberikan dapat efektif, untuk peneliti selanjutnya dapat melihat faktor pendukung lain seperti asupan makanan secara keseluruhan dan kontribusi (persentase) Makanan Tambahan terhadap asupan makanan, serta untuk puskesmas perlu dilakukan pencatatan evaluasi konsumsi PMT sehingga menjadi evaluasi untuk penilaian efektivitas Pemberian Makanan Tambahan.

\section{DAFTAR PUSTAKA}

Afriza, R. (2016). Analisis Determinan Status Gizi Balita (6-59 bulan) Berdasarkan Composite Index of Anthropometric Failure (CIAF) di Wilayah Kerja Puskesmas Nanggalo Kota Padang Tahun 2016. Program Studi Kesehatan Masyarakat Program Pascasarjana Universitas Andalas.

Herianto, P. N. (2017). Efektivitas Pemberian Makanan Tambahan Pemulihan (PMT-P) Terhadap Kenaikan Berat Badan Balita Gizi Kurang di Wilayah Kerja Puskesmas Tlogomulyo
Kabupaten

Temanggung. Universitas Alma Ata.

Juhartini. (2015). Pengaruh Pemberian Makanan Tambahan Biskuit dan Bahan Makanan Campuran Kelor Terhadap Berat Badan dan Tinggi Badan Pada Balita Gizi Kurang di Wilayah Kerja Puskesmas Kalumpang Kota Ternate. Jurnal Kesehatan, VIII(1), 1-8.

Kementerian Kesehatan. (2017). Hasil Pemantauan Status Gizi (PSG) Tahun 2016.

Kementerian Kesehatan. (2018). Buku Saku Pemantauan Status Gizi Tahun 2017.

Kementerian Kesehatan. (2019). Hasil Utama Riskesdas 2018.

Putri, A. S. R., \& Mahmudiono, T. (2020). Efektivitas Pemberian Makanan Tambahan (PMT) Pemulihan Pada Status Gizi Balita di Wilayah Kerja Puskesmas Simomulyo, Surabaya. https://doi.org/10.20473/amn t.

Sugianti, E. (2017). Evaluasi Pemberian Makanan Tambahan Pemulihan (PMT-P) Pada Balita Kurang Gizi di Kabupaten Tuban. Jurnal Cakrawala, 11(2), 217-224.

WHO. (2018). Global Nutrition Report 2018 - Executive Summary. https://doi.org/10.2499/9780 896295643 